\title{
Physicochemical and biochemical characterizations of some Tunisian seed oils ${ }^{\text {th }}$
}

\author{
Iness J. Karoui, Jihene Ayari*, Nessrine Ghazouani and Manef Abderrabba \\ Laboratory of Materials, Molecules and Applications, IPEST, Road Sidi Bou Said, BP 51, La Marsa, Tunisia
}

Received 1 April 2019 - Accepted 12 July 2019

\begin{abstract}
Four Tunisian vegetable oils extracted from seeds (Nigella sativa, Opuntia ficus indica, Pistacia lentiscus and Hibiscus sabdariffa) have been characterized in this study. The following parameters were determined: acidity, peroxide value, saponification value, specific extinction coefficients K232, K270, chlorophylls and carotenoids content. The triglyceride and tocopherol compositions of the oils were determined using reversed phase high performance liquid chromatography with diode array detection (HPLC-DAD) and the fatty acids (FA) and phytosterol compositions were determined using a gas chromatography (GC) with a flame ionization detector (FID). Polyunsaturated fatty acids were predominant in all tested samples except in Pistacia lentiscus oil where monounsaturated fatty acids were predominant. Major FA were linoleic and oleic acids. $\beta$-sitosterol was the most abundant phytosterol. All samples had high content of TAGs with an equivalent carbon number of 44, 46 and 48 . Nigella sativa oil had the highest content of tocopherols.
\end{abstract}

Keywords: Nigella sativa oil / Opuntia ficus indica oil / Pistacia lentiscus oil / Hibiscus sabdariffa oil

Résumé - Caractérisations physico-chimiques et biochimiques de quelques huiles de graines tunisiennes. Quatre huiles végétales tunisiennes extraites de graines (Nigella sativa, Opuntia ficus indica, Pistacia lentiscus et Hibiscus sabdariffa) ont été caractérisées dans cette étude. Les paramètres suivants ont été déterminés : acidité, indice de peroxyde, indice de saponification, coefficients d'extinction spécifiques K232, K270, teneur en chlorophylles et en caroténoïdes. Les compositions en triglycérides et tocophérol des huiles ont été déterminées par chromatographie liquide haute performance en phase inverse avec détection à barrette de diodes (HPLC-DAD) et les compositions d'acides gras (FA) et de phytostérol ont été déterminées à l'aide d'une chromatographie en phase gazeuse (GC) couplée à un détecteur à ionisation de flamme (FID). Les acides gras polyinsaturés étaient prédominants dans tous les échantillons testés, à l'exception de l'huile de Pistacia lentiscus où les acides gras mono-insaturés prédominaient. Les principaux acides aminés étaient les acides linoléique et oléique. Le $\beta$-sitostérol était le phytostérol le plus abondant. Tous les échantillons avaient une teneur élevée en triacylglycérols (TAG) avec un nombre de carbone équivalent de 44, 46 et 48 . L'huile de Nigella sativa avait la teneur la plus élevée en tocophérols.

Mots clés : huile de Nigella sativa / huile d'Opuntia ficus indica / huile de lentille de Pistacia / huile d'Hibiscus sabdariffa

\section{Introduction}

Humans have used vegetable oils for centuries and still using it nowadays in food, medicine, cosmetics and as fuels (Thomas, 2000; Durrett et al., 2008; Montero de Espinosa and Meier, 2011). Plants generally accumulate oil in their seeds and

\footnotetext{
Contribution to the Topical Issue "Minor oils from atypical plant sources / Huiles mineures de sources végétales atypiques"

*Correspondence: jihene.ayari@fst.utm.tn
}

fruits to provide energy for germination and the early stages of seedling development, which make seeds good sources of edible oils.

Oilseed crops are primarily grown for edible oil. Recently, oilseeds attracted more attention due to an increasing demand for their healthy vegetable oils, livestock feeds, pharmaceuticals, biofuels, and other oleochemical industrial uses. The increased interest resulted in an $82 \%$ expansion of oilseed crop cultivation areas and about a $240 \%$ increase in total world production over the last 30 years (Rahman and Jiménez, 2016). 


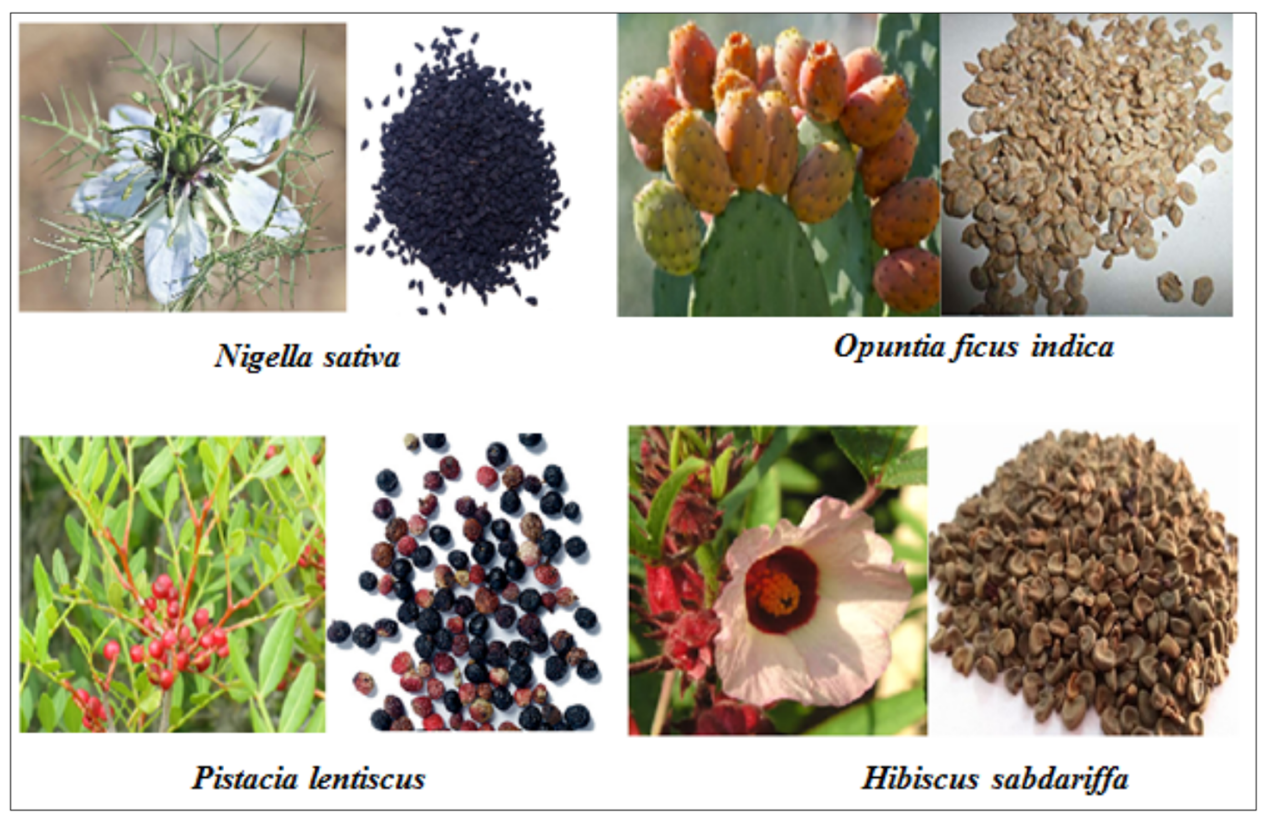

Fig. 1. Plant material.

Fats and oils are the most concentrated kind of energy that all living organisms can use (Odoemelam, 2005; Aliyu et al., 2010; Barua et al., 2011). The suitability of oil for certain application and a particular purpose is determined by its characteristics, fatty acid and triglyceride compositions (Alvarez and Rodriguez, 2000; Akpabio et al., 2012).

Using the physical and chemical properties, we can judge vegetable oils quality. Therefore, in this perspective, we have decided to compare four Tunisian seed oils Nigella sativa, Opuntia ficus indica, Hibiscus sabdariffa and Pistacia lentiscus and to investigate their physicochemical, fatty acids, sterols and tocopherol compositions in order to conclude their potential uses.

\section{Experimental procedures}

\subsection{Plant material}

Four oil samples: extracted from black cumin (Nigella sativa. L), prickly pear (Opuntia ficus indica), lentisk (Pistacia lentiscus L) and hibiscus (Hibiscus sabdariffa L) seeds (Fig. 1) were provided by the National Office of Oil in Tunisia during the $2016 / 2017$ season. Oil samples were stored at $4{ }^{\circ} \mathrm{C}$ and protected from sunlight prior analysis.

\subsection{Determination of the physicochemical characteristics of seed oils}

\subsubsection{Determination of free acidity}

Acidity is one of the chemical characteristics of the oil used to indicate its quality and to determine its grade (IOC, 2015). The expression of free acidity content was as percent of oleic acid. The free acidity of the oil samples was determined according to the ISO 660 method (AOCS Cd 3d-63) amending Regulation (EEC No. 2568/91), which consists in determining the fatty acids released during the hydrolysis of triglycerides with a sodium hydroxide solution.

\subsubsection{Determination of the peroxide value}

The peroxide value (PV) determined according to ISO 3960 (AOCS Cd 8b-90) measures the number of hydroperoxides present in the oil and formed by auto-oxidation during storage. The expression of $\mathrm{PV}$ was as milliequivalent of active oxygen per kilogram of oil (Meq $\mathrm{O}_{2} / \mathrm{kg}$ oil).

\subsubsection{Determination of the saponification index}

The saponification number, which is determined according to ISO 3657 (AOCS Cd3-25), is the amount of potassium hydroxide necessary to saponify one gram of fat and is expressed as $\mathrm{mg} \mathrm{KOH} / \mathrm{g}$ of fat.

\subsubsection{Determination of extinction coefficients specific for $K_{232}$ and $K_{270}$}

Extinction coefficients $\left(K_{232}\right.$ and $\left.K_{270}\right)$ were determined according to (AOCS Ch 5-91).

The use of ultraviolet absorbance coefficients provides information on the presence or absence of primary and secondary oxidation products in the oil (Tanouti et al., 2011). The higher the values of $K_{232}$ and $K_{270}$, the more the oil is rich in oxidation products.

Extinction coefficient $\left(K_{232}\right.$ and $\left.K_{270}\right)$ is the specific extinction of a $1 \%(\mathrm{w} / \mathrm{v})$ solution of oil in cyclohexane in $1 \mathrm{~cm}$ cell path length, using a CARY 100 Varian UV spectrometer.

\subsubsection{Determination of chlorophyll and carotenoids content}

The analysis of the pigments (chlorophylls and carotenoids) was determined according to Mínguez-Mosquera et al. (1991) method.

The absorbance of a flask filled up with $7.50 \mathrm{~g}$ of oil mixed with $25 \mathrm{ml}$ of pure cyclohexane was measured relative to that of the solvent at $670 \mathrm{~nm}$ for chlorophylls and at $470 \mathrm{~nm}$ for 
Table 1. Oils quality indices.

\begin{tabular}{llllllll}
\hline Oil & \multicolumn{1}{c}{ Acidity } & Peroxide value & Saponification index & Carotenoid & Chlorophyll & $K_{232}$ & $K_{270}$ \\
\hline Nigella Sativa & $3.11 \pm 0.01^{\mathrm{c}}$ & $4.11 \pm 0.025^{\mathrm{d}}$ & $190.25 \pm 0.05^{\mathrm{b}}$ & $1.81 \pm 0.002^{\mathrm{b}}$ & $2.02 \pm 0.01^{\mathrm{b}}$ & $2.05 \pm 0.001^{\mathrm{b}}$ & $0.37 \pm 0.005^{\mathrm{a}}$ \\
Opuntia ficus indica & $0.27 \pm 0.005^{\mathrm{a}}$ & $3.71 \pm 0.1^{\mathrm{c}}$ & $190.13 \pm 0.1^{\mathrm{b}}$ & $1.08 \pm 0.05^{\mathrm{c}}$ & $2.15 \pm 0.01^{\mathrm{c}}$ & $1.65 \pm 0.01^{\mathrm{a}}$ & $0.29 \pm 0.005^{\mathrm{a}}$ \\
Pistacia lentiscus $_{\text {Hibiscus sabdariffa }}$ & $4.14 \pm 0.02^{\mathrm{d}}$ & $1.92 \pm 0.07^{\mathrm{b}}$ & $189.12 \pm 0.1^{\mathrm{a}}$ & $9.73 \pm 0.02^{\mathrm{d}}$ & $8.91 \pm 0.02^{\mathrm{d}}$ & $2.13 \pm 0.005^{\mathrm{c}}$ & $0.43 \pm 0.15^{\mathrm{a}}$ \\
\hline
\end{tabular}

Values are given as mean $\pm \mathrm{SD}(n=3)$. Values followed by the same letter did not share significant differences at $p<0.05$ (Duncan's test).

carotenoids using a spectrophotometer (T60 UV-Visible spectrophotometer PG INSTRUMENTS). The pigment content was determined by the following formulas:

$$
\begin{aligned}
& \text { Chlorophylls }(\mathrm{ppm})=\left(\mathrm{A}_{670} * 106\right) /(E 1 * 100 * d), \\
& \text { Carotenoids }(\mathrm{ppm})=\left(\mathrm{A}_{470} * 106\right) /(E 1 * 100 * d),
\end{aligned}
$$

E1: extinction coefficient; d: diameter of the tank.

\subsection{Composition of oils}

\subsubsection{Composition in free fatty acids}

Fatty acid composition was determined following regulation $\mathrm{EEC} / 2568 / 91$ (EEC/2568, 2003). Before analysis, fatty acids (FAs) were converted to fatty acid methyl esters (FAMEs) by transesterification of triglycerides with methanolic potassium hydroxide $(2 \mathrm{~N})$.

FAMEs were analyzed by gas chromatography using an Agilent Technologies 6890 Network GC System chromatograph equipped with a FID. A split injector used and the injected volume was $1 \mu \mathrm{l}$. The column used was a RT-2340 type, $(60 \mathrm{~m} \times 0.25 \mathrm{~mm} \times 0.25 \mu \mathrm{m})$. The carrier gas was helium and the total gas flow rate was $1 \mathrm{~mL} / \mathrm{min}$. The initial and final column temperature was 170 and $230^{\circ} \mathrm{C}$, respectively, and steps of $4^{\circ} \mathrm{C} / \mathrm{min}$ increased the temperature. The injector and detector temperature was $230^{\circ} \mathrm{C}$. The elution is therefore carried out in order of increasing molecular weights $(\mathrm{C} 16, \mathrm{C} 18, \ldots)$ and the number of insturations $(\mathrm{C} 18$, C18: 1, C18: 2, ...). Fatty acids were identified by their retention times.

Results expressed as the relative percentage of each individual FA present in the sample.

\subsubsection{Triglyceride composition}

Total TAGs were separated according to the equivalent carbon number (ECN), defined as the total $\mathrm{CN}$ in the fatty acid acyl chains minus twice the number of DB per molecule $(\mathrm{ECN}=\mathrm{CN}-2 \mathrm{DB})$, through the application of a high performance liquid chromatography (HPLC) (Agilent 1100, Santa Clara, Calif., USA), equipped with an auto-injector.

The triacylglycerols were separated using an RP-18 column $(250 \times 4 \mathrm{~mm})$ with a particle size of $5 \mu \mathrm{m}$ and eluted from a column with a mixture of acetonitrile/acetone $(50 / 50)$ at a flow rate of $1 \mathrm{~mL} / \mathrm{min}$. Twenty microliters of the mixture $(0.5 \mathrm{~g}$ of oil diluted in $10 \mathrm{~mL}$ of acetone) was injected into the HPLC column.

\subsubsection{Sterol composition}

Sterol composition was determined using the NFT 60-254 method as previously described (Hilali et al., 2005).

The trimethylsilyls were analyzed using gas chromatography (Agilent Technologies 6890 N Network GC System) equipped with a CP-SIL-5CB apolar capillary column $(30 \mathrm{~m} \times 0.25 \mathrm{~mm} \times 0.25 \mu \mathrm{m})$. The injector's temperature was of $230{ }^{\circ} \mathrm{C}$. At the outlet of the column maintained at $210^{\circ} \mathrm{C}$, the compounds were detected by a FID detector (flame ionization detector) brought to a temperature of $250^{\circ} \mathrm{C}$. The flow rate of the carrier gas (helium) was $1.5 \mathrm{ml} / \mathrm{min}$ and the injected volume was $5 \mu \mathrm{l}$.

\subsubsection{Quantification of tocopherols}

The quantitative analysis of the tocopherols was determined using a Waters e2695 High Performance Liquid Chromatography (HPLC), equipped with an UV detector at $280 \mathrm{~nm}$ by injecting a solution of $20 \mathrm{mg}$ of oil mixed in hexane and isopropanol (99:1) and filtered using a $0.45 \mu \mathrm{m}$ filter. The capillary column $(4.6 \mathrm{~mm} \times 25 \mathrm{~cm})$ used is apolar ODS-2 $5 \mathrm{~mm}$. The mobile phase was composed of $4 \% \mathrm{~A}$ and $96 \% \mathrm{~B}$ $\left(\mathrm{A}=0.5 \% \mathrm{H}_{2} \mathrm{PO}_{4}\right.$ in water; $\mathrm{B}=$ Acetone/Acetonitrile $(50 / 50)$. The flow rate was set at $1.5 \mathrm{ml} / \mathrm{min}$. The detection wavelength was at $292 \mathrm{~nm}$. The quantification of tocopherols was performed using an external standard method and expressed in $\mathrm{mg} / \mathrm{kg}$. (ISO 9936, 2006).

\section{Statistical analysis}

All data reported are the means $\pm \mathrm{SE}$ of three repetitions. Significance of differences between samples was calculated by the ANOVA procedure, using a significance level of $P \leq 0.05$.

\section{Results and discussion}

\subsection{Physicochemical characterization of oils}

According to Table 1, Opuntia ficus indica oil represents the lowest free acidity $(0.27 \pm 0.005)$ followed by Hibiscus sabdariffa oil $(0.55 \pm 0.003)$, then Nigella sativa $(3.11 \pm 0.01)$ and finally Pistacia lentiscus oil with a value of $4.14 \pm 0.02$ of oleic acid. All founded values were within the range normally encountered for crude vegetable oils.

Our results are comparable to that of Boukeloua (2009) who found a free acidity value for Pistacia lentiscus oil about $2.955 \pm 0.03$. 
Mahmoud et al. (2016) studied the physicochemical parameters of the oil of Hibiscus seeds grown in Egypt and found a free acidity about 0.78 higher than our findings.

This may be due to the presence of fatty acids released by the action of lipase on triglycerides during crushing seeds since free acidity controls the level of hydrolytic, enzymatic or chemical degradation of triglyceride fatty acid chains (Abaza et al., 2002).

Concerning the peroxide values shown in Table 1, Nigella sativa oil has the highest value $\left(4.11 \pm 0.025 \mathrm{meq}_{2} / \mathrm{kg}\right.$ fat $)$, followed by Opuntia ficus indica oil about $3.71 \pm 0.1$, then the oil of Pistacia Lentiscus about $1.92 \pm 0.07$ and Hibiscus sabdariffa oil which is characterized by the lowest one about $0.28 \pm 0.08$.

Detection of peroxide reveals the current level of oxidative rancidity in unsaturated fats and oils and indicates the oxidation state of the fat.

All samples presented PV values inferior to $5 \mathrm{meq} \mathrm{O}_{2} / \mathrm{kg}$ fat which lead us to conclude that tested oils are considered to have a low oxidation.

Mahmoud et al. (2016) found a higher peroxide value of Hibiscus seeds oil grown in Egypt about 4.82.

The highest saponification index, as shown in Table 1, was found in Hibiscus sabdariffa oil $(193.5 \pm 0.25 \mathrm{mg} \mathrm{KOH} / \mathrm{g})$ and the lowest one was found in Pistacia Lentiscus oil $(189.1 \pm 0.1 \mathrm{mg} \mathrm{KOH} / \mathrm{g})$. On the other hand, the rest of tested oils have almost the same index: Nigella sativa oil was about $190.25 \pm 0.05 \mathrm{mg} \mathrm{KOH} / \mathrm{g}$ and the seed oil of Opuntia ficus indica was about $190.10 \pm 0.1 \mathrm{mg} \mathrm{KOH} / \mathrm{g}$.

Because there is an inverse relationship between saponification value and weight of fatty acids in the oils, it can be assumed that the oils hold fatty acids with 16-18 carbon atoms with a significant amount of saturated fatty acids in the case of the P. lentiscus oil (Charef et al., 2008).

The chemical examinations of the oils as used in this study were in agreement with the other vegetables oils reported in the literature (Karlenskind 1992).

Our results are comparable to that of Boukeloua (2009) who found a saponification value for Pistacia lentiscus oil about 197.75 to $200.45 \mathrm{mg} \mathrm{KOH} / \mathrm{g}$.

Mahmoud et al. (2016) found a higher saponification index of Hibiscus seeds oil grown in Egypt about $196.68 \mathrm{mg}$ $\mathrm{KOH} / \mathrm{g}$.

Chlorophylls and carotenoids are involved in auto and photo-oxidation mechanisms (Cheikh-Rouhou et al., 2007). They are responsible for the color of the oil, which is a very important attribute to evaluate its quality.

According to Table 1, the carotenoid and chlorophyll contents for Nigella sativa oil were $1.81 \pm 0.002 \mathrm{mg} / \mathrm{kg}$ and $2.02 \pm 0.01 \mathrm{mg} / \mathrm{kg}$, respectively. Chlorophyll content is much lower than that evaluated by Cheikh-Rouhou et al. (2007) which was about $6.04 \mathrm{ppm}$.

Opuntia ficus oil contains the lowest carotenoid content $(1.08 \pm 0.05 \mathrm{mg} / \mathrm{kg})$ and chlorophyll content about $(2.15 \pm 0.01 \mathrm{mg} / \mathrm{kg})$.

Pistacia lentiscus oil contains the highest amounts of carotenoids $\quad(9.73 \pm 0.02 \mathrm{mg} / \mathrm{kg})$ and chlorophyll $(8.91 \pm 0.02 \mathrm{mg} / \mathrm{kg})$.

The carotenoids and chlorophyll contents in Hibiscus sabdariffa oil were $1.49 \pm 0.002 \mathrm{ppm}$ and $1.41 \pm 0.008 \mathrm{ppm}$, respectively.
In a study done by Ramadan and Mörsel (2003), the assessment of carotenoids levels was limited to beta-carotene, which represented $0.42 \mathrm{mg} / \mathrm{kg}$ in pulp oil, but higher than that in the seed oil. They also explained that pigment content depends on the stage of fruit maturity, extraction process and storage conditions.

The highest extinction coefficient $\mathrm{K}_{232}$ was found in Pistacia lentiscus oil $(2.13 \pm 0.005)$, followed by that of Hibiscus sabdariffa oil $(2.12 \pm 0.005)$, then Nigella sativa which is equal to $2.05 \pm 0.001$ and finally Opuntia ficus indica oil $(1.65 \pm 0.01)$.

Concerning $\mathrm{K}_{270}$, results for all tested oils were close to each other, respectively; for Opuntia ficus indica oil $(0.29 \pm 0.005)$; for Pistacia lentiscus $(0.43 \pm 0.15)$, for Hibiscus sabdariffa oil $(0.32 \pm 0.004)$ and finally for Nigella sativa oil which is equal to $0.37 \pm 0.005$.

The $K$ values measured at $232 \mathrm{~nm}$ and $270 \mathrm{~nm}$ are associated with changes in the content of conjugated dienes and trienes formed due to polyunsaturated fatty acids oxidation. It is a measure of oxidation/rancidity and oil quality (Abdulkarim et al., 2007).

Generally, $K_{232}$ increase due to inappropriate storage of fruits or old-fashioned extraction or standardization procedure. On the other hand, $\mathrm{K}_{270}$ increase when the oil is not fresh and results from a previous harvesting.

\subsection{Composition of oils}

Fatty acid composition is an important characteristic for vegetable oils analyzed using a gas chromatography (GC). Values listed in Table 2 showed a significant variation between the tested samples due probably to the quality of seeds (maturity, storage conditions...), and genetic causes (plant cultivation...).

Polyunsaturated fatty acids constitute the major fraction of total fatty acids in Nigella sativa oil, representing a total of $58.79 \%$ and containing basically linoleic acid (C18:2), oleic acid $(\mathrm{C} 18: 1)$ and palmitic acid as major saturated fatty acid with a proportion of $(58.6 ; 24.21 ; 12.91 \%)$. This result is in agreement with that found by Cheikh-Rouhou et al. (2007) who demonstrated that polyunsaturated fatty acids represent a content of $50.7 \pm 0.70 \%$ for Tunisian oil of Nigella sativa seeds. Toparslan (2012) have cited some similar results found in Ethiopian, Indian and Syrian Nigella sativa seeds, respectively: linoleic acid (58; 54.68 and $54.13 \%$ ), oleic acid $(23.46,25.65,24.51 \%)$ and palmitic acid $(12.07,13.15$, $14.64 \%)$.

The fatty acid profile and the high levels of polyunsaturated fatty acids make Nigella sativa oil a special component for nutritional applications.

Results in the Figure 2 showed that PUFA represents the major fraction of total fatty acids (59.56\%) in the Opuntia ficus indica seed oil, followed by monounsaturated fatty acids representing a content of $24.07 \%$. Almost the same result was observed with Nigella sativa, in which the PUFA represents $58.79 \%$ and monounsaturated fatty acids represents a content of $24.81 \%$. These criteria make the classification of both samples to the category of polyunsaturated oils like most vegetable oils. It is composed mainly by linoleic and oleic acid giving it a great similarity with corn oil. This result is in agreement with the result of Bhira (2012). 
Table 2. Fatty acid composition of the different vegetable oils in (\%).

\begin{tabular}{lcccc}
\hline Compounds & Nigella sativa oil & Opuntia ficus indica oil & Pistacia lentiscus oil & Hibiscus sabdariffa oil \\
\hline $\mathrm{C}_{14: 0}$ Myristic A & 0.19 & 0.1 & 0.04 & 0.24 \\
$\mathrm{C}_{16: 0}$ Palmitic A & 12.91 & 12.05 & 24.12 & 19.12 \\
$\mathrm{C}_{16: 1} \omega 7$ Palmitoleic A & 0.25 & 0.75 & 0.2 & 0.31 \\
$\mathrm{C}_{17: 0}$ Heptadecanoic A & 0.06 & 0.04 & 0.09 & 0.12 \\
$\mathrm{C}_{17: 1}$ Heptadecanoic A & 0.06 & 0.04 & 1.19 & 0.08 \\
$\mathrm{C}_{18: 0}$ Stearic A & 3.03 & 3.8 & 52.88 & 5.07 \\
$\mathrm{C}_{18: 1} \omega 9$ Oleic A & 24.21 & 23.08 & 16.76 & 33.23 \\
$\mathrm{C}_{18: 2} \omega 6$ Linoleic A & 58.6 & 59.33 & 0.39 & 40.79 \\
$\mathrm{C}_{18: 3} \omega 3$ Linolenic A & 0.19 & 0.23 & 0.11 & 0.19 \\
$\mathrm{C}_{20: 0}$ Arachidic A & 0.17 & 0.35 & 0.13 & 0.75 \\
$\mathrm{C}_{20: 1} \omega 9$ Eicosenoic A & 0.29 & 0.2 & 25.52 & 0.07 \\
SFA & 16.36 & 16.43 & 17.15 & 25.3 \\
$\sum$ PUFA & 58.79 & 59.56 & 55.3 & 40.98 \\
$\sum$ MUFA & 24.81 & 24.07 & 33.69 \\
\hline
\end{tabular}

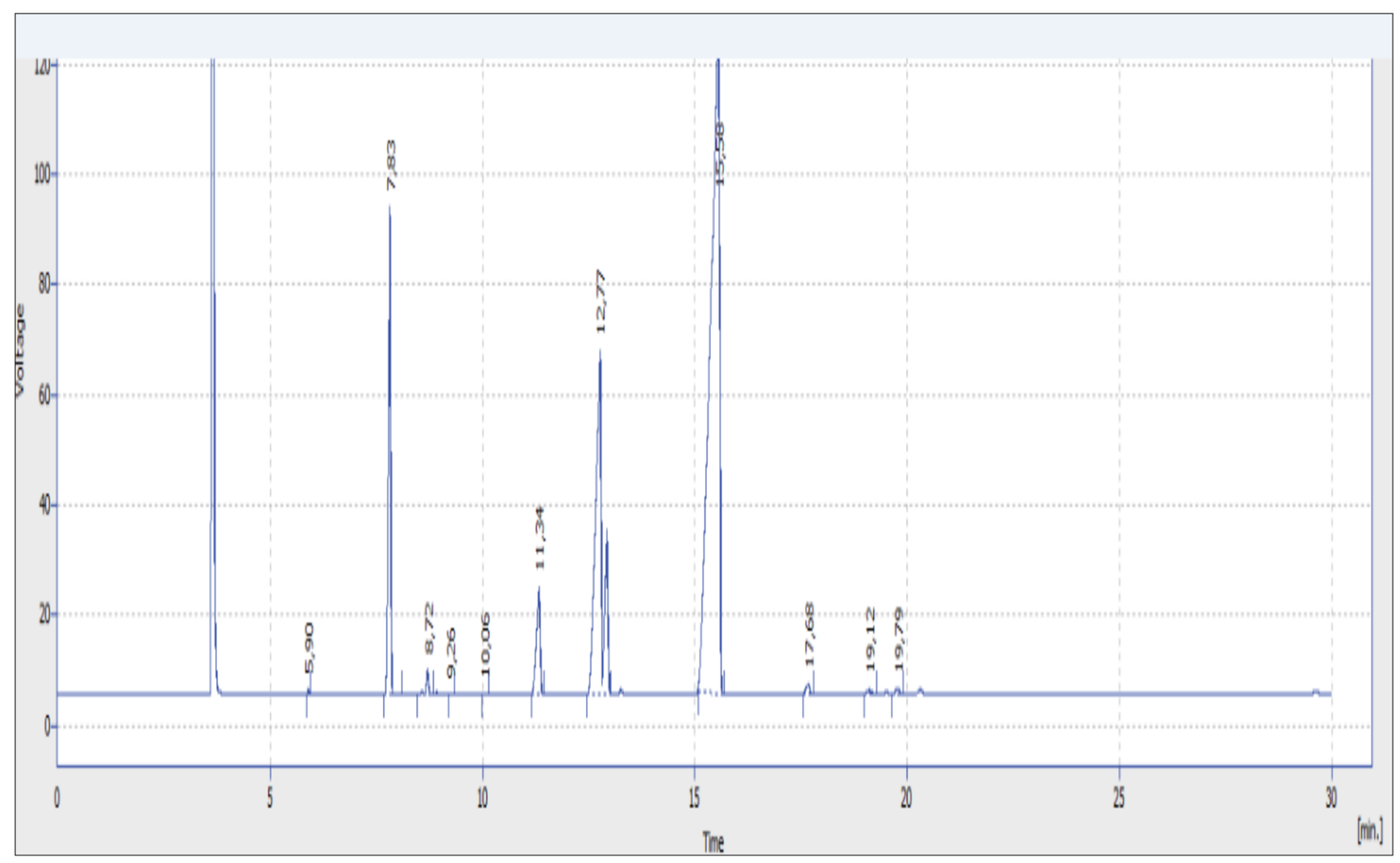

Fig. 2. Chromatogram of the fatty acids in Opuntia ficus indica oil.

The works of Ramadan and Mörsel (2003) have shown that the fatty acid composition of prickly pear oil is highly influenced by climatic factors, soil type and genetic factors in which the seeds are grown.

Tlili et al. (2011) showed that the unsaturated fatty acids of Opuntia ficus indica seeds harvested for three different years represent a high content of unsaturated fatty acids $(83.2 \%)$, linoleic acid, with $56.60 \%$, was the main fatty acid, followed by oleic acid $(20.10 \%)$.
Pistacia lentiscus oil has a major fraction of monounsaturated fatty acids (55.3\%), of which oleic acid is the major compound $(52.88 \%)$. This result is similar to that found by Charef et al. (2008) who demonstrated that oleic acid represents a proportion of $55.3 \pm 0.8 \%$ in the oil of Pistacia lentiscus.

The studies of Dhifi et al. (2013) showed that the first class of fatty acids contained in Tunisian Pistacia lentiscus oil were dominated by monounsaturated fatty acids representing 
Table 3. Triglyceride composition of the vegetable oils (\%).

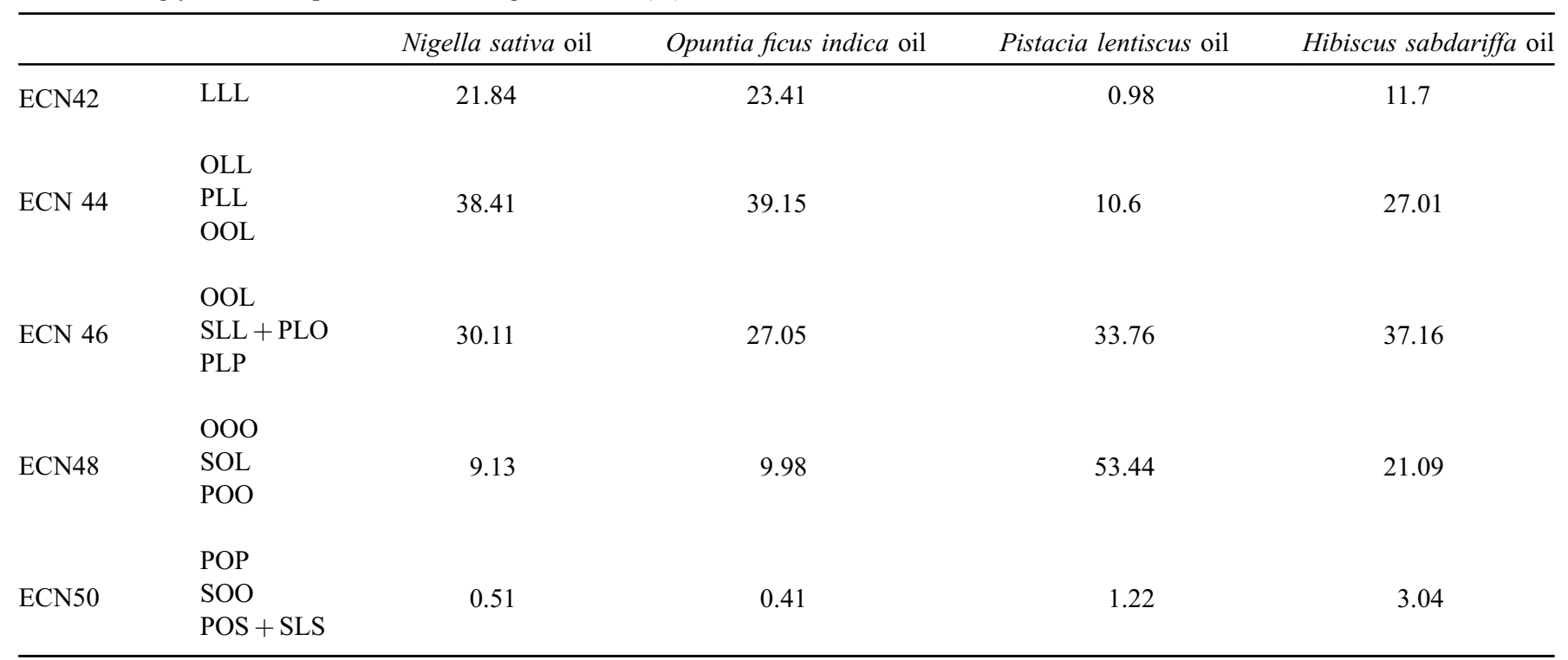

LLL: trilinoleoyl-glycerol; OLL: oleyl-dilinoleoyl-glycerol; PLL: palmitoyl-dilinoleoyl-glycerol; OOL: dioleyllinoleoylglcerol; SLL: stearoyldilinoleoylglycerol; POL: palmitoyl-oleyl-linoleoylglycerol; PPL: dipalmitoyllinoleoylglycerol; OOO: trioleylglycerol; SOL: stearoyloleyllinoleoylglycerol; POO: palmitoyl-dioleylglycerol; PPO: dipalmitoyl-oleylglycerol.

$52.40 \%$ of all fatty acids. Saturated fatty acids and polyunsaturated fatty acids accounted for $26.42 \%$ and $21.18 \%$ of total fatty acids, respectively. The major fatty acid was oleic acid with a quantity of $51.06 \%$. Linoleic acid (C18: 2 ), which is an essential fatty acid, accounted for $20.71 \%$ of total fatty acids.

Polyunsaturated and monounsaturated fatty acids are the major fatty acids in Hibiscus sabdariffa oil with proportions of 40.98 and $33.69 \%$, respectively, of which the major fatty acid is linoleic acid with a content of $40 \%$. Then, there is oleic acid with a rate of $33.23 \%$. This result is contradictory with that found by Eltayeib and AbdElaziz (2014) who showed that the main fatty acid is oleic acid with a percentage of $47.88 \%$ followed by linoleic acid (30.79\%).

Cissouma et al. (2013) found in their study that oleic and linoleic acids had the highest values of 33.07 and $35.16 \%$, respectively. Of the unsaturated fatty acids, palmitoleic acid was the lowest $(0.32 \%)$, while palmitic acid $(18.76 \%)$ was the most abundant saturated fatty acid.

The fatty acid composition showed a high content of unsaturated fatty acids, particularly linoleic acid (35.16\%).

TAGs with an equivalent carbon number of 44 represent major proportions $(38.41 \% ; 39.15 \%)$ respectively in Nigella sativa and Opuntia ficus indica seeds oils as shown in Table 3. HPLC analyses revealed three individual TAGs: OLL; PLL; OOL.

Gharby et al. (2015) identified nine triacylglycerols in Opuntia oil. The most important are LLL (24.94\%), LLO (21.31\%), LLP (15.90\%) and OOL (13.76\%).

TAGs with an equivalent carbon number equal to 46 represent the major fraction in Hibiscus sabdariffa oil with $37.16 \%$. HPLC analyses revealed two individual and one combined TAGs: OOL; SLL + PLO and PLP.

However, for Pistacia lentiscus oil, TAGs with an equal carbon number equal to 48 represent the major fraction with
$53.44 \%$ as shown in Figure 3. HPLC analyses revealed three individual TAGs OOO; SOL and POO. This result is in agreement with that reported by Dhifi et al. (2013) who found that the majority of the triacylglycerols are in mono and polyunsaturated form and the main constituents were $\mathrm{SO}+$ OOP representing $27.58 \%$ of total TAG.

Using sterols in vegetable oils, we can identify their composition and determine their quality. It has been reported to be unaffected by environmental factors and/or culture (Ramadan and Mörsel, 2007). Sterols make up about 2\% of the oil and are free and esterified sterols.

$\beta$-sitosterol is the major sterol in all tested samples $(88.22-$ $67.04 \%$ ) as listed in Table 4 , which is the main phytosterol of olive oil and found in many seeds (Ramadan and Mörsel, 2003). This sterol is known for its ability to reduce prostate tumors and strengthening immunity (Rakel, 2018).

$\beta$-sitosterol is the major sterol found in Nigella sativa oil with a content of $67.04 \%$, followed by stigmasterol $(14.14 \%)$ and campesterol (13.43\%) and then $\delta 5-24$ stigmastadienol, $\delta 7-$ stigmastenol and $\delta 7$-avenasterol. Cheikh-Rouhou et al. (2007) found lower proportion of $\beta$-sitosterol in Tunisian and Iranian Nigella sativa oil (44.5 and 53.9\%, respectively).

The major sterols found in Opuntia oil were $\beta$-sitosterol $(82.31 \%)$ and campesterol (10.66\%). Ramadan and Mörsel (2003) found lower percentage of $\beta$-sitosterol in their study that was around $72 \%$.

The major sterol in Pistacia lentiscus oil was $\beta$-sitosterol with a proportion of $82.31 \%$ followed by campesterol $(6.41 \%)$, stigmasterol $(2.25 \%)$ and cholesterol $(0.50 \%)$. Dhifi et al. (2013) had found in their study a much lower proportion of $\beta$-sitosterol $(55.55 \%)$ and a higher percentage of cholesterol about $44.45 \%$.

The major sterols found in Hibiscus sabdariffa oil were $\beta$-sitosterol (79.08\%), campesterol (12.28\%) and stigmasterol 


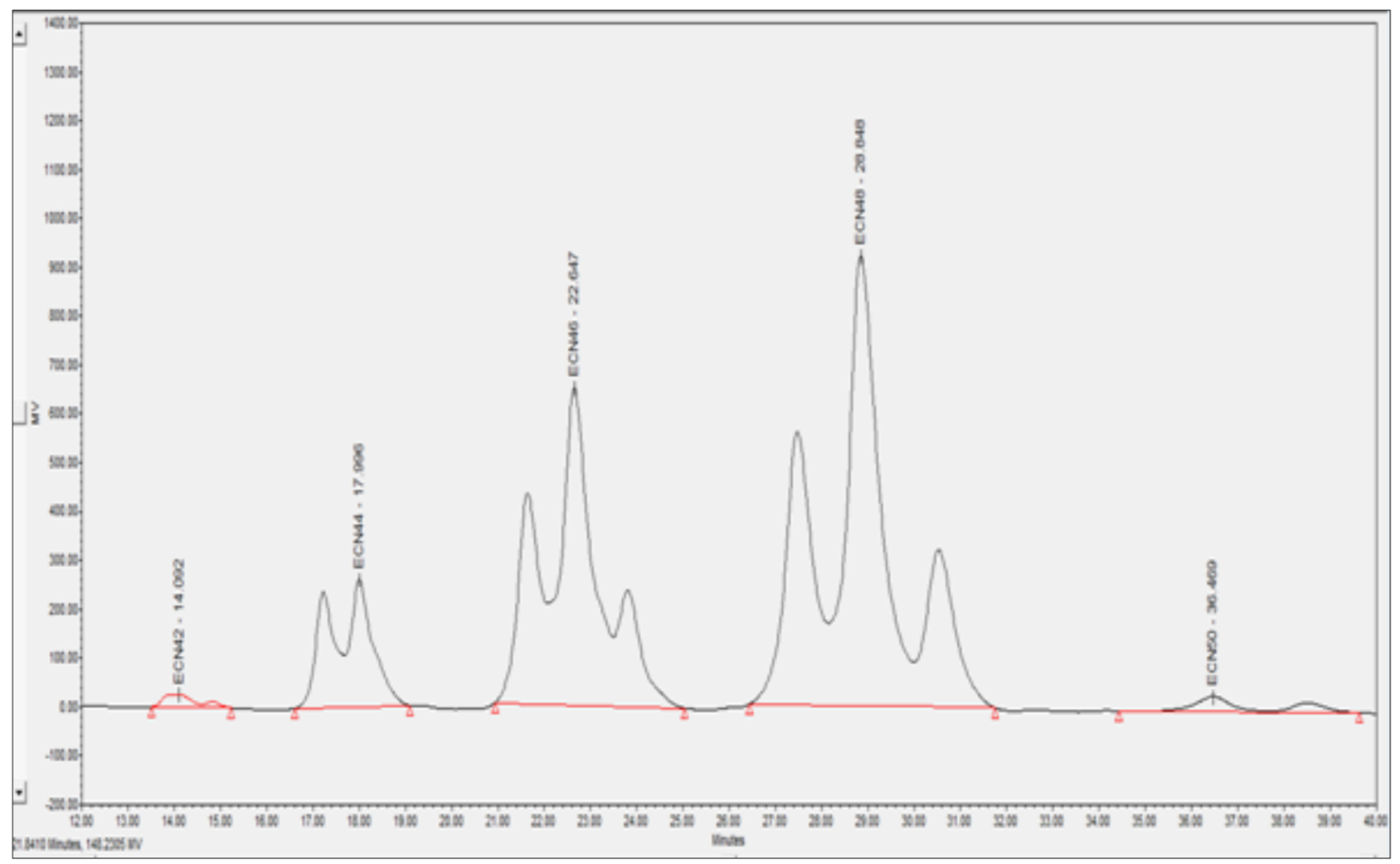

Fig. 3. HPLC Chromatogram of triglycerides of Pistacia lentiscus oil.

Table 4. Sterol composition of the vegetable oils (\%).

\begin{tabular}{lcccc}
\hline & Nigella sativa oil & Opuntia ficus indica oil & Pistacia lentiscus oil & Hibiscus sabdariffa oil \\
\hline Cholesterol & 0.91 & 0.91 & 0.9 & 1.41 \\
Brassicasterol & 0.06 & 0 & 0 & 0.17 \\
Campesterol & 13.43 & 10.66 & 6.41 & 12.85 \\
Stigmasterol & 14.14 & 1.4 & 2.25 & 3.3 \\
Chlerosterol & 0.82 & 0.99 & 0.72 & 0.49 \\
$\beta$-sitosterol & 67.04 & 82.31 & 88.22 & 0.41 \\
$\Delta^{5}$-24stigmastadienol & 1.22 & 0.96 & 0.58 & 0.75 \\
$\Delta^{7}$-stigmastenol & 0.7 & 1.14 & 0.34 & 0.01 \\
$\Delta^{7}$-avenasterol & 1.65 & 1.62 & 0.89 \\
\hline
\end{tabular}

(3.3\%). In addition, cholesterol is present in a rate of $1.41 \%$. These results are comparable to those of Ramadan and Mörsel (2007) who found that the percentage of $\beta$-sitosterol was $71.9 \%$, followed by campesterol $(13.6 \%)$ and cholesterol $(1.35 \%)$.

According to Mohamed et al. (2007), the sterols of Hibiscus sabdariffa $L$ seed oil include $\beta$-sitosterol (71.9\%), campesterol $(13.6 \%), \Delta 5$-avenasterol $(5,9 \%)$, cholesterol $(1.35 \%)$ and clerosterol $(0.6 \%)$.

Opuntia ficus indica and Hibiscus sabdariffa seed oils were characterized by the highest amount of total sterols followed by that in Pistacia lentiscus and Nigella sativa oils, as shown in Table 5.
The interest in phytosterols these recent years lies in their potential to decrease coronary mortality and reduce plasma low-density lipoprotein cholesterol level (Gul and Amar, 2006).

Cholesterol found in trace amounts about $1 \%$ in all tested samples.

Tocopherols are naturally occurring antioxidants with biological activity (Matthäus and Özcan, 2011). They are responsible for the oxidative stability of the oil and protect fatty acids by eliminating free radicals and reactive oxygen species. The composition of tocopherols varies according to the species and, within the same species according to the genotypes (Demir and Cetin, 1999). 
Table 5. Total sterols and tocopherols content of different oils.

\begin{tabular}{lcc}
\hline Vegetable oil & $\begin{array}{c}\text { Total sterols } \\
(\mathrm{mg} / \mathrm{Kg})\end{array}$ & $\begin{array}{c}\text { Tocopherols } \\
(\mathrm{mg} / \mathrm{Kg})\end{array}$ \\
\hline Nigella sativa oil & 1034 & 480 \\
Opuntia ficus indica oil & 1623 & 479 \\
Pistacia lentiscus oil & 1380 & 273 \\
Hibiscus sabdariffa oil & 1613 & 371.67 \\
\hline
\end{tabular}

Nigella sativa oil have a tocopherol content about $480 \mathrm{mg} /$ $\mathrm{kg}$ followed by the one in Opuntia ficus indica $(479 \mathrm{mg} / \mathrm{kg})$, then Pistacia lentiscus oil (273 mg/kg) and finally in Hibiscus sabdariffa oil $(371.67 \mathrm{mg} / \mathrm{kg})$, as shown in Table 5 .

Ramadan and Mörsel (2002) reported that seed oil of Nigella contains a significant amount of tocopherols in which $\alpha$-tocopherol is the major compound (48\%).

According to Gharby et al. (2015), the total tocopherol content of Opuntia oil from Morocco, Tunisia and Germany was $946,447.2$ and $403 \mathrm{mg} / \mathrm{kg}$, respectively. Y-tocopherol $(90 \%)$ was the major constituent.

According to Dhifi et al. (2013) Pistacia lentiscus oil contained $8111.137 \mathrm{mg}$ of tocopherols $/ \mathrm{kg}$ of oil higher than our findings. $\alpha$-tocopherol, which has the highest antioxidant activity accounted for $97 \%$ of the total tocopherols in Pistacia lentiscus oil.

Tocopherols detected by Mohamed et al. (2007) and Ramadan and Mörsel (2007) were at an average concentration of $2000 \mathrm{mg} / \mathrm{kg}$, including $\alpha$-tocopherol (25\%) $\gamma$-tocopherol $(74.50 \%)$ and $\delta$-tocopherol $(0.50 \%)$.

Consumption of food rich in natural antioxidants is protective against some types of cancer and may reduce the risk of cardiovascular and cerebrovascular events Aruoma (1998). These actions of antioxidants attributed to their ability to scavenge free radicals, thereby reducing oxidative damage of cellular biomolecules such as lipids, proteins, and nucleic acids (Ferguson, 1995). This richness in tocopherols, including the predominance of $\alpha$-tocopherol, which is a very good antioxidant fatty phases, contributes to the natural protection and conservation of the oil against oxidation.

\section{Conclusion}

Recently, there has been an increased interest in antioxidant activity and the ability to improve health. It is therefore important to promote aromatic and medicinal plants (AMP) that have the most popular source of these active substances and incorporate them into our eating habits.

Highlighting physicochemical and biochemical analyzes of four vegetable oils extracted from the seeds in this study permitted a conclusion of their oxidative activity and their potential incorporation in some foods in order to ameliorate their storage.

According to this study, the seeds of Nigella sativa, Opuntia ficus indica, Pistacia lentiscus and Hibiscus sabdariffa seemed to be a good source of antioxidant agents. Different parameters were studied to check the sample's quality and freshness and a deep investigation of their composition revealed interesting fatty acids, sterols and TAGs content. Linoleic, oleic and palmitic acids were predominant which are important in cognition and motor activity and have beneficial physiological effects in the prevention of cardiovascular diseases and cancer. $\beta$-sitosterol is a phytosterol with high benefits in prevention of cancer and strengthening immunity.

An interesting nutritional composition characterized all tested oils. Such study could lead to many industrial applications.

Acknowledgements. The authors are grateful to National Office of Oil in Tunisia for providing oils (NOO).

Conflicts of interest. The authors declare that they have no conflicts of interest in relation to this article.

\section{References}

Abaza L, Mongi M, Douja D, Zarrouk M. 2002. Caractérisation des huiles de sept variétés d'olivier tunisiennes. OCL 9(2): 174-179.

Abdulkarim SM, Long K, Lai OM, Muhammad SKS, Ghazali HM. 2007. Frying quality and stability of high-oleic Moringa oleifera seed oil in comparison with other vegetable oils. Food Chem 105: 1382-1389.

Akpabio UD, Akpakpan AE, Udo UE, Essien UC. 2012. Physicochemical characterization of exudates from Raffia Palm (Raphia hookeri). Adv Appl Sci Res 3(2): 838-843.

Aliyu A, Kuhiyop E, Hamza A. 2010. Extraction and characterization of landolphia seed oil. Adv Appl Sci Res 1(3): 265-268.

Alvarez AMR, Rodriguez MLG. 2000. Lipids in pharmaceutical and cosmetic preparations. Grasas y Aceites 51(Fasc. 1-2): 74-96.

Aruoma OI. 1998. Free radicals, oxidative stress and antioxidants in human health and disease. J Am Oil Chem Soc 75: 199-212.

Barua D, Buragohain J, Sarma SK. 2011. Certain physico-chemical changes in the soil brought about by contamination of crude oil in two oil fields of Assam, NE India. Eur J Exp Biol 1(3): 154-161.

Bhira O. 2012. Potentialités thérapeutiques d'opuntia ficus Indica en Maroc et en Tunisie. Thèse en pharmacie, Université Mohamed V. Rabat. Disponible sur http://ao.um5s.ac.ma/xmlui/handle/ 123456789/1754.

Boukeloua A. 2009. Effect of virgin fatty oil of Pistacia lentiscus on experimental burn wound's healing in rabbits. Afr J Trad CAM 7 (3): $258-263$.

Charef M, Mohamed Yousfi M, Saidiet PS. 2008. Determination of the fatty acid composition of acorn (Quercus), Pistacia lentiscus seeds growing in Algeria. J Am Oil Chem Soc 85: 921-924.

Cheikh-Rouhou S, Besbes S, Hentati B, Blecker C, Deroanne C, Attia H. 2007. Nigella sativa L.: chemical composition and physicochemical characteristics of lipid fraction. Food Chem 101: 673-681.

Cissouma AI, Tounkara F, Nikoo M, Yang N, Xueming Xu. 2013. Physico chemical properties and antioxidant activity of roselle seed extracts. J Food Sci Technol 5(11): 1483-1489.

Demir C, Cetin M. 1999. Determination of tocopherols, fatty acids and oxidative stability of pecan, walnut and sunflower oils. Dtsch Lebensmitt Rundsch 95: 278-282.

Dhifi W, Nahida J, Emna C, et al. 2013. Chemical composition of Lentisk (Pistacia lentiscus L.) seedoil. Afr J Agric 8(16): 395 1400 .

Durrett TP, Benning C, Ohlrogge J. 2008. Plant triacylglycerols as feed stocks for the production of biofuels. Plant J 54: 593-607.

EEC/2598. 2003. Commission of the European Communities. Regulation $2568 / 91$ on the characteristics of olive oil and olive-residues and on relevant methods of analysis. Off $J$ Eur Commun L248: 1-109. 
Eltayeib AA, AbdElaziz A. 2014. Physicochemical properties of Roselle (Hibiscus sabdariffa L.) seeds oil (Elrahad-1) in North Kordofan, Sudan. J Sci Innov Res 3(6): 578-582.

Ferguson L. 1995. Pistachio production. Center of Fruit and Nut Crop Research and Information. University of California at Davis. Department of Pomology, 2037 Wickson Hall. Davis, CA95616 USA, p. 160.

Gharby S, Harhar H, Charrouf Z, Bouzobaa Z, Boujghagh M, Zine S. 2015. Physicochemical composition and oxidative stability of Opuntia ficus-indica seed oil from Morocco. Acta Hortic 1(1067): 83-88.

Gul MK, Amar S. 2006. Sterols and the phytosterol content in oilseed rape (Brassicanapus L.). J Cell Mol Biol 5: 71-79.

Hilali M, Charrouf Z, Soulhi AEA, Hachimi L, Guillaume D. 2005. Influence of origin and extraction method on argan oil physicochemical characteristics and composition. J Agric Food Chem 53: 2081-2087.

IOC. 2015. COI/T.15/NC n ${ }^{\circ}$ 3/Rév. 8 février 2015 français Original : français.

ISO 9936. 2006. Animal and vegetable fats and oils-Determination of tocopherol and tocotrienol contents by high-performance liquid chromatography. pp. 1-17.

ISO 3960:2001 or AOCS Cd 8b-90. Peroxide value.

ISO 660 or AOCS Cd 3d-63(99). Free acidity.

Karlenskind A. 1992. Manuel des corps gras. Tome 1. Paris: Technique et documentation Lavoisier, pp 116-226.

Mahmoud MS, Nadia TA, Sobhy AS, et al. 2016. Assessment of Theileria equi and Babesia caballi infections in equine populations in Egypt by molecular, serological and hematological approaches. Parasit Vectors. DOI: 10.1186/s13071-016-1539-9.

Matthäus B, Özcan MM. 2011. Fatty acids, tocopherol, and sterol contents of some Nigella Species seed oil. Food Chem 130: 326-332.

Mínguez-Mosquera MI, Gandul-Rojas B, Montãno-Asquerino A, Garrido-Fernández J. 1991. Determination of chlorophylls and carotenoids by high-performance liquid chromatography during olive lactic fermentation. J Chromatogr 585: 259-266.
Mohamed R, Fernández J, Pineda M, Aguilar M. 2007. Roselle (Hibiscus sabdariffa) seed oil is a rich source of gammatocopherol. J Food Sci 72(3): S207-S211.

Montero de Espinosa L, Meier MAR. 2011. Plant oils: The perfect renewable resource for polymer science. Eur Polym J47, 837-852.

Odoemelam SA. 2005. Proximate composition and selected phytochemical properties of African Oil bean (Penthaclethra Macrophylla). Pak J Nutr 4(6): 382-383.

Rahman M, Jiménez MM. 2016. Designer oil crops. Chapter 15. In: Gupta SK, ed. Breeding oilseed crops for sustainable production. Opportunities and Constraints. United States: Elsevier, pp. 361-376.

Rakel MD. 2018. Benign prostatic hyperplasia. Chapter 60. In: Integrative medicine (Fourth Edition). United States: Elsevier, pp. 601-607.

Ramadan MF, Mörsel JT. 2002. Direct isocratic normal-phase HPLC assay for fat soluble vitamins and $\beta$-carotene in oil seeds. Eur food Res Technol 214: 521-527.

Ramadan MF, Mörsel JT. 2003. Oil cactus pear (Opuntia ficus indica L.). Food Chem 82: 339-345.

Ramadan MF, Mörsel JT. 2007. Impact of enzymatic treatment on chemical composition, physicochemical properties and radical scavenging activity of goldenberry (Physalis peruviana L.) juice. J Sci Food Agric 87(3): 452-460.

Tanouti K, Serghini-Caid H, Chaieb E, Benali A, Harkous M, Elamrani A. 2011. Amélioration qualitative d'huiles d'olive produites dans le Maroc Oriental. Les Technologies de Laboratoire 6(22): 1-12.

Thomas A. 2000. Fats and fatty oils. In: Wiley-VCH Verlag GmbH \& Co. KGaA, eds. Ullmann's Encyclopedia of Industrial Chemistry. Weinheim, Germany: Wiley-VCH Verlag GmbH \& Co. KGaA. ISBN: 978-3-527-30673-2.

Tlili N, Bargougui A, Elfalleh W, Triki S, Nasri N. 2011. Phenolic compounds, protein, lipid content and fatty acids compositions of cactus seeds. J Med Plants Res 5(18): 4519-4524.

Toparslan C. 2012. À propos de Nigella sativa L. Thèse d'État de Doctorat en Pharmacie. Université de Lorraine.

Cite this article as: Karoui IJ, Ayari J, Ghazouani N, Abderrabba M. 2020. Physicochemical and biochemical characterizations of some Tunisian seed oils. OCL 27: 29. 